\title{
The analysis of the parenting implications on the emotional closeness of parent-child improvement
}

\author{
Zadrian Ardi ${ }^{1}$, Galang Zaki Aulia ${ }^{1}$ \\ ${ }^{1}$ Universitas Negeri Padang, Indonesia
}

\begin{tabular}{l} 
Article Info \\
\hline Article history: \\
Received Aug $22^{\text {nd }}, 2020$ \\
Revised Sep $19^{\text {th }}, 2020$ \\
Accepted Oct $11^{\text {th }}, 2020$ \\
\hline
\end{tabular}

\section{Keyword:}

Improvement

Parent-child closeness

Parenting

\section{Corresponding Author:}

Zadrian Ardi,

Universitas Negeri Padang

Email: zadrian@fip.unp.ac.id

\begin{abstract}
The development of science and knowledge and the structure of society has had various impacts on the order of social life. No exception influences the smallest organization, namely the family. The model and parenting patterns of the previous generation (the baby boomers' generation) are significantly different from the next generation. Of course, this also causes differences in the results and impacts obtained. However, the issues related to parenting tend to remain the same. One parenting that is often used is authoritarian parenting, in which parent's tom much impose his will on the child as desired. This makes children become depressed so that the proximity of the child with parents rift or loose. The purpose of this study is to analyze the implications of parenting conditions and its various characteristics in building closeness between parents and children.
\end{abstract}

(C) 2020 The Authors. Published by Redwhitepress.

This is an open access article under the CC BY-NC-SA license

(https://creativecommons.org/licenses/by-nc-sa/4.0/

\section{Introduction}

The proximity of the parents with children are often the main reason for the problems in natural by children, especially children who are going through the development and need guidance from parents (Fouts \& Silverman, 2015; H. Lee et al., 2015; Maguire-Jack \& Klein, 2015). This happens because most parents do apply parenting are ineffective or inappropriate parenting towards the child. In parenting, the proper parenting should be considered for the child's development and is also one of the main factors to be relations of the immediacy of the elderly (Larzelere, Gunnoe, Roberts, \& Ferguson, 2017).

Parenting is the most prominent parent behavior, i.e. by way of disciplining children, instilling the values of life on children, teach life skills, and manage emotions so that children can form the concept of the self (Johnston \& Fletcher, 2015; Maguire-Jack \& Klein, 2015; Rodriguez, Hartley, \& Bolt, 2019; Schoeps, Valero-Moreno, Perona, Pérez-Marín, \& Montoya-Castilla, 2020). We can discipline the child with ways to say it subtly but firmly, don't get used to snap or hit, children will quickly against if we snap or hit, and then, if children make mistakes parents give children the consequences, tell the children that the actions were wrong and give additional tasks as a consequence, for example, sweep the house, clean rooms and so on, and do not involve themselves for conflict with the child, parents often happen easily triggered angry and wanted to hit the child (Khade, Wang, \& Decker, 2018; Sadik, 2018; Wang \& Liu, 2018). This will only make the closeness of parent and child loose. Hurlock (1973) suggests that parental behavior influence parenting children adhered them is authoritarian parenting which actions arranged by the parents, permissive parenting in which parents too followed the whims of children. The parents who use permissive parenting a chance to do a reasonable sexual behavior as much as three times greater than the child who is taken care of with authoritative pattern 
(Democratic) by her parents, parenting democratic in which children participated in the ask a question or objection if the parents make the rules (Lo, Lai, $\mathrm{Ng}, \&$ Wang, 2020). Based on an examination of the form of parenting that is applied by a parent, not a few parents who apply the form of inappropriate parenting on children, parenting the most ubiquitous in the environment of the community i.e. authoritarian parenting and permissive parenting, which is where the less parenting instilling ethical values and more emphasis to the physical needs of physical needs. In applying good moral behavior, the parent should apply the parenting of democracy, as in parenting, there are many aspects in developing good moral behavior for the child (Gustafsson, 2019; Nihayati, Sholihah, \& Qonaah, 2020).

If the parent is already implementing parenting is right and proper, then the closeness of parent and child will be awake, let alone in a period now is very hard to maintain the closeness of parent and child with many factors that affect the proximity of parent and child. The closeness as an emotional bond between parent and child, which is the relative length of the relationship and has significance and cannot be replaced by anyone. Proximity or attachment between parents and children is an important aspect that must be owned by a parent in an effort so that the child can be easily guided. Stickiness or proximity is a strong emotional bond that developed through interactions with people that have a special meaning in his life, usually parents.

\section{Discussions}

The closeness between parents with children (certainly influenced the development of the child) in this day a lot of family harmony is reduced because the child is not close to parents (Acar, Torquati, Encinger, \& Colgrove, 2018; Gallo et al., 2019; Sette, Baldwin, Zava, Baumgartner, \& Coplan, 2019; Taylor, Marquis, Coall, \& Werner, 2018). The closeness of behavior that is a form of behavior that sustains closeness with several different individuals. Whareas the closeness between parent and child can provide many advantages in child development. The advantages of the proximity of parent and child is the parent providing a secure base on the child and can encourage the child to explore themselves. Children who are close to the parents often make parents responsive and a lot of help when children have problems. One factor that loosens the closeness of parent and child is the application of parenting. A mother who spent more time with bad behavior will hamper the development of the child. It is this proximity that impacts the closeness in the future. Besides, it will negatively affect the child's interest as described, non-involvement parents in reading activity will result in children who are not interested in reading. The role of parents is very important in maintaining the closeness of a parent with children and also keep the child's development (Sette et al., 2019; Taylor et al., 2018). Hurlock (1973) States in the process of growing flower child, it takes on the role of parents, which is a very important thing. While the role of the parents should understand and recognize kids with a good attitude and unique talents, develop and nurture their personality without forcing him to be someone else. In addition to the role of the family, environmental factors also affect child development. Dispositions and the environment is a factor that influenced the development of the child (Guyer et al., 2015; Jalu, Ahmed, Hashi, \& Tekilu, 2019; Mistretta, 2020; Sidabrienè, 2014).

If the proximity of parent and child is good, then it will give a positive impact, as described by Hurlock (1973) relationships with family members, affects the Foundation of our attitude toward society, and life in general. Besides a positive impact from the proximity of the parents and children, the proximity of the child with the parent will enrich a child with social welfare such as self-esteem, adjustment of emotions, and physical health (Choi, Schoeni, Wiemers, Hotz, \& Seltzer, 2020; Elldér, Larsson, Solá, \& Vilhelmson, 2018; W. J. Han, Whetung, \& Mao, 2020). Children who are close to the parents often make parents responsive and a lot of help when children have problems. There is a pattern of the relationship between the parents of the child, such as the pattern of the relationship between parent-child can be distinguished into several patterns i.e. accepting the presence of the child in child discipline, excessive, exaggerated in spoiling children, rejecting the presence of children. Parenting greatly affects the proximity of parent and child (Moscarola, Fornero, \& Rossi, 2018; Neuman \& Knapczyk, 2020; Sacchi \& Viazzo, 2018).

Parenting is the pattern of interaction between parent and child which includes in it the fulfillment of children's physical needs such as food and drink, and also covers the psychological needs such as safety, compassion, comfortable protection, and others, as well as provide an understanding of the norms in force in the community so that the child can live in harmony or blend in with their surroundings (Bradley, Iida, Pennar, Owen, \& Vandell, 2017; Ciciolla, Curlee, Karageorge, \& Luthar, 2017; Czymoniewicz-Klippel, Chesnut, DiNallo, \& Perkins, 2019; Dicé, Maiello, Dolce, \& Freda, 2017). Parenting is an intensive interaction where parents steer children to have life skills. Understanding parenting also includes that parents help children in completing the tasks of their development. Parenting is the interaction between the child and parent interaction in which parents educate, guide, and discipline as well as protecting children which will

Journal homepage: http://journal.redwhitepress.com/index.php/jles 
enable the child to achieve the tasks its development (Theisen \& Emblem, 2018; Tieken, 2020; Westford, 2018).

Every parent has a different understanding of how to implement parenting, not all parents apply the same parenting. Every parent is different in applying to parent and their behavior towards children. It depends on the attitude that they are learning in a nurturing and educating children, among others, the existence of initial experience with children, the knowledge of how to best treat the child either in democratic or authoritarian, permissive (Bradley et al., 2017; Ciciolla et al., 2017; Czymoniewicz-Klippel et al., 2019; Dicé et al., 2017). Most parents apply authoritarian parenting which authoritarian parenting harms children. Authoritarian parenting is parenting that limit the will of the child and the child's demands to always follow the orders of parents. This will make the children do not have confidence, and to make children afraid to state his opinion and make children be covered. The children of authoritarian parenting are applied will have difficulty in a particular behavior. Those who grew up in the family tend to be less authoritarian showed curiosity and emotions-positive emotions as well as less likely to be able to get along (Giallo et al., 2018; Gu, 2018; Herbers, Garcia, \& Obradović, 2017; Jones-Mason, Alkon, Coccia, \& Bush, 2018). In addition to authoritarian parenting that gives a negative impact on children, permissive parenting can also give a negative impact. Permissive parenting makes children too spoiled and wayward boys against parental orders, parents who apply permissive parenting educating her son as best as possible but tend to be very passive when until the problem of the determination of the boundaries or respond to infidelity. Child applies permissive parenting tend to be less disciplined. The parents who apply permissive parenting tend to want to always be liked and the child growing up without being given an understanding for responsible responsibility and discipline (Negreiros, Ballester, Valero, Carmo, \& Gama, 2019; Niec, 2018; Piermattei, Pace, Tambelli, D’Onofrio, \& Di Folco, 2017).

The application of good parenting will affect the child's development in the future, one of the authoritative parenting. Shapiro (1999) suggested "in terms of learning, parents who apply authoritative parenting give encouragement and praise to the son. Good treatment of a mother will make children think positively about themselves and their surroundings (Simons, Wu, Conger, \& Lorenz, 2017; Tadjuddin, Elfiah, Meriyati, Wekke, \& Saregar, 2019; Tissot, Kuersten-Hogan, Frascarolo, Favez, \& McHale, 2019; Tu, Gregson, Erath, \& Pettit, 2017). This can lead to the child being able to explore the optimal environment, and optimal child development is made anyway (Stams, 2002). Vice versa, many parents are wrong in applying to the parent that will have an impact on the development of the child. Andayani (2001) through his work "A Focused on Child Abuse in Six Selected Provinces in Indonesia", found in the public sphere and domestic that most parents go wrong in treating his son (maltreated). Not just affects child development but also the formation of his character. The fault of parents at the time educating children will affect the development of children's emotional intelligence to affect the formation of his character. The treatment of children who threaten the welfare of the child to grow and develop optimally both physical, social, psychological, mental and spiritual, are the wrong treatment so that the child does not have a strong personal character as a fortress in itself. The character is the image of ourselves and a reflection of your attitude and manners. The characters are the qualities or mental or moral strength, morals, or character of an individual who is a special personality that became the catalyst and driving force, as well as the difference with the other individual (Rote \& Smetana, 2018; Shawler \& Funderburk, 2019; Simon \& Brooks, 2019).

The application of the wrong parenting can also create child aggression. One factor that influences aggressiveness is parenting. Parenting parents greatly affect children's aggressive behavior. In addition to the parenting wrong, the atmosphere in the house also affects the mindset of children, the home atmosphere that often causes conflict, can make the atmosphere between family members not comfortable can cause children to feel stress, insecurity, and discomfort. The negative impact of that is a rampant crime in doing by a child, a case that many now are crimes where many do by children (Popa, 2018; Radey, Schelbe, McWey, \& Holtrop, 2017; Rebollo \& González, 2019).

The attitude of overprotective conducted the parent is also the mistake that a lot happens, overprotective attitude that is excessive protection that makes the child a chance to learn from their environment be covered, so that the child can not adapt to the environment. Besides, the sense of overprotective, namely the excessive protection that can make children uncomfortable. Many parents apply the attitude of overprotective in children which would cause a negative impact. Characteristics of the overprotective parents will be reflected in the behavior of the child, for these traits is her every day a child's behavior raises self-doubts, feelings of insecurity, fear of doing something, be pessimistic, and difficult to socialize/hang out with his friends. The attitude of the overprotective usually occurs on the youngest male, an only child, child adoption, children in need special and orphans, or orphans (Jones-Mason et al., 2018; M. K. Lee, Baker, \& Whitebread, 2018; Ma \& Grogan-Kaylor, 2017; Piermattei et al., 2017). 
In addition to the impacts of the application of the wrong parenting that already described, the positive impact of the application of the parenting right is to make children independently $(\mathrm{Gu}, 2018$; $\mathrm{Z}$. R. Han et al., 2019). The independence of the child from the family and influenced by parenting the parent. The sense of independence doing everything by their self, not suspended on others, and be able to account for his actions. Another sense of independence is the process by which a person in control of their learning, in particular learning how to set goals, find the right resources, determine the method of learning used and evaluate their learning progress (Koss, Cummings, Davies, \& Cicchetti, 2017; M. K. Lee et al., 2018; Leith, Yuill, \& Pike, 2018). The characteristics of the self-sufficient child we can see from her confidence, as described, the characteristics of independence was responsible, thinking before acting, confident, and creative. In addition to that described, the characteristics of independence are emotional independence, self-reliance, and independence Act of thinking. Through parenting, parents should be able to foster children, effort to cultivate children's independence by helping children build confidence himself. Usually, in adolescence, the child was to be self-sufficient because the supposed teenager is not dependent on the parent. At the beginning of the age of the adolescents, the sign is already self-sufficient is not dependent on parents anymore (Ma \& Grogan-Kaylor, 2017; Marini, Collins, \& MacDermid Wadsworth, 2018; Negreiros et al., 2019).

Parenting is very influential in children especially in adolescence in which teenagers need guidance from parents, and by adolescence, this knowledge will be broad, good parenting affects development in children, especially in the time of adolescence, where teenagers must complete its development tasks well (Popa, 2018; Simon \& Brooks, 2019; Tu et al., 2017). Teenager is the change from childhood towards adulthood which includes changes in physical, cognitive, and social changes. The role of parenting and the role of parents is very important in adolescence, if the parent is wrong in applying to parents then it will affect the behavior of adolescents (Cantero-García \& Alonso-Tapia, 2017; Dicé et al., 2017; Herbers et al., 2017; Shawler \& Funderburk, 2019; Simon \& Brooks, 2019). The family factor is one of the factors that influence the behavior of adolescents. If families applying the correct parenting then teenagers would be close to the parents. As described by Hurlock, teens will think positively about themselves when the people that matter to him are enjoying them, and vice versa (Hurlock, 1973). In addition to the family, the environment is also becoming an important factor in their development of teenagers, an important factor during the development of adolescents is behavior, environmental and personal/cognition. Adolescents desperately need guidance, If not right in taking decisions at the time of the conflict takes place, they will fall into the risky behavior and will bear the consequences she continued in the form of a variety of physical and psychosocial health problems, that might even have to bear all his life.

\section{Conclusions}

Can be concluded that parenting that is applied by the parent to the child, is very influential in maintaining the closeness of parent and child. Many parents do not understand the true parenting so bad on the proximity of the parents and the child. Authoritarian and permissive parenting that will give a negative impact on child development parent are often used. The application of correct parenting will give a positive impact to the development of children and will keep the closeness between parent and child. Recommended for parents should understand in advance about parenting that will be applied. Parenting demokratif is good parenting. Parents should also understand the mindset of children, do not be too overprotektif attitudes in children applying, because it will make the child be covered and not independent. Parents should be clever in guiding and disciplining children.

\section{References}

Acar, I. H., Torquati, J. C., Encinger, A., \& Colgrove, A. (2018). The role of child temperament on lowincome preschool children's relationships with their parents and teachers. Infant and Child Development, 27(1). doi:10.1002/icd.2045

Bradley, R. H., Iida, M., Pennar, A., Owen, M. T., \& Vandell, D. L. (2017). The Dialectics of Parenting: Changes in the Interplay of Maternal Behaviors during Early and Middle Childhood. Journal of Child and Family Studies, 26(11), 3214-3225. doi:10.1007/s10826-017-0805-6

Cantero-García, M., \& Alonso-Tapia, J. (2017). Evaluation of the family climate created by the management of behavioral problems, from the perspective of the children. Electronic Journal of Research in Educational Psychology, 15(2), 259-280. doi:10.14204/ejrep.42.16062

Choi, H., Schoeni, R. F., Wiemers, E. E., Hotz, V. J., \& Seltzer, J. A. (2020). Spatial Distance Between Parents and Adult Children in the United States. Journal of Marriage and Family, 82(2), 822-840. doi:10.1111/jomf.12606 
Ciciolla, L., Curlee, A. S., Karageorge, J., \& Luthar, S. S. (2017). When Mothers and Fathers Are Seen as Disproportionately Valuing Achievements: Implications for Adjustment Among Upper Middle Class Youth. Journal of Youth and Adolescence, 46(5), 1057-1075. doi:10.1007/s10964-016-0596-x

Czymoniewicz-Klippel, M., Chesnut, R., DiNallo, J., \& Perkins, D. (2019). Patterns of participation in the Grow parenting program. Journal of Children's Services, 14(1), 27-41. doi:10.1108/JCS-06-2018-0014

Dicé, F., Maiello, A., Dolce, P., \& Freda, M. F. (2017). Dialogic transformations of preoccupations in pediatric primary care: An empirical inquiry. Psicologia della Salute(3), 74-96. doi:10.3280/PDS2017003004

Elldér, E., Larsson, A., Solá, A. G., \& Vilhelmson, B. (2018). Proximity changes to what and for whom? Investigating sustainable accessibility change in the Gothenburg city region 1990-2014. International Journal of Sustainable Transportation, 12(4), 271-285. doi:10.1080/15568318.2017.1363327

Fouts, H. N., \& Silverman, L. S. (2015). Parenting and Environmental Risk: An Examination of Child Loss and Maternal Involvement among Bofi Foragers in Central Africa. Human Nature, 26(1), 73-88. doi:10.1007/s12110-015-9221-z

Gallo, L. C., Roesch, S. C., Bravin, J. I., Savin, K. L., Perreira, K. M., Carnethon, M. R., . . Isasi, C. R. (2019). Socioeconomic Adversity, Social Resources, and Allostatic Load Among Hispanic/Latino Youth: The Study of Latino Youth. Psychosomatic medicine, 81(3), 305-312. doi:10.1097/PSY.0000000000000668

Giallo, R., Gartland, D., Woolhouse, H., Mensah, F., Westrupp, E., Nicholson, J., \& Brown, S. (2018). Emotional-behavioral resilience among children of first-time mothers with and without depression across the early childhood period. International Journal of Behavioral Development, 42(2), 214-224. doi: $10.1177 / 0165025416687413$

Gu, M. M. (2018). Family acculturation, parent style, and ethnic minority students' identity construction in Hong Kong. In Home-School Relations: International Perspectives (pp. 155-174): Springer Singapore.

Gustafsson, K. (2019). Selective parenting programs for parents with foreign backgrounds: cultural imperialism or democratic practices in social work? Nordic Social Work Research, 1-13.

Guyer, A. E., Jarcho, J. M., Pérez-Edgar, K., Degnan, K. A., Pine, D. S., Fox, N. A., \& Nelson, E. E. (2015). Temperament and Parenting Styles in Early Childhood Differentially Influence Neural Response to Peer Evaluation in Adolescence. Journal of abnormal child psychology, 43(5), 863-874. doi:10.1007/s10802-0159973-2

Han, W. J., Whetung, T., \& Mao, X. (2020). One Roof, Three Generations: Grandparental Co-residence and Child Outcomes in China. Family Process, 59(3), 1144-1160. doi:10.1111/famp.12484

Han, Z. R., Gao, M. M., Yan, J., Hu, X., Zhou, W., \& Li, X. (2019). Correlates of Parent-Child Physiological Synchrony and Emotional Parenting: Differential Associations in Varying Interactive Contexts. Journal of Child and Family Studies, 28(4), 1116-1123. doi:10.1007/s10826-019-01337-4

Herbers, J. E., Garcia, E. B., \& Obradović, J. (2017). Parenting Assessed by Observation versus Parent-report: Moderation by Parent Distress and Family Socioeconomic Status. Journal of Child and Family Studies, 26(12), 3339-3350. doi:10.1007/s10826-017-0848-8

Hurlock, E.B. (1973). Perkembangan Anak. Jakarta: Erlangga.

Jalu, M. T., Ahmed, A., Hashi, A., \& Tekilu, A. (2019). Exploring barriers to reproductive, maternal, child and neonatal (RMNCH) health-seeking behaviors in Somali region, Ethiopia. PLOS one, 14(3). doi:10.1371/journal.pone.0212227

Johnston, C. A., \& Fletcher, A. C. (2015). Prediction of maternal use of friendship facilitation strategies in middle childhood. Journal of Social and Personal Relationships, 32(7), 946-966. doi: $10.1177 / 0265407514554518$

Jones-Mason, K., Alkon, A., Coccia, M., \& Bush, N. R. (2018). Autonomic nervous system functioning assessed during the still-face paradigm: A meta-analysis and systematic review of methods, approach and findings. Developmental Review, 50, 113-139. doi:10.1016/j.dr.2018.06.002

Khade, N. B., Wang, X., \& Decker, S. H. (2018). Examining the Link Between Childhood Physical Abuse and Risk for Violent Victimization in Youth and Young Adulthood in China. Journal of interpersonal violence. doi:10.1177/0886260518794002

Koss, K. J., Cummings, E. M., Davies, P. T., \& Cicchetti, D. (2017). Patterns of Adolescent Regulatory Responses During Family Conflict and Mental Health Trajectories. Journal of Research on Adolescence, 27(1), 229-245. doi:10.1111/jora.12269

Larzelere, R. E., Gunnoe, M. L., Roberts, M. W., \& Ferguson, C. J. (2017). Children and parents deserve better parental discipline research: Critiquing the evidence for exclusively "positive" parenting. Marriage \& Family Review, 53(1), 24-35. 
Lee, H., Tamminen, K. A., Clark, A. M., Slater, L., Spence, J. C., \& Holt, N. L. (2015). A meta-study of qualitative research examining determinants of children's independent active free play. International Journal of Behavioral Nutrition and Physical Activity, 12(1). doi:10.1186/s12966-015-0165-9

Lee, M. K., Baker, S., \& Whitebread, D. (2018). Culture-specific links between maternal executive function, parenting, and preschool children's executive function in South Korea. British Journal of Educational Psychology, 88(2), 216-235. doi:10.1111/bjep.12221

Leith, G., Yuill, N., \& Pike, A. (2018). Scaffolding under the microscope: Applying self-regulation and otherregulation perspectives to a scaffolded task. British Journal of Educational Psychology, 88(2), $174-191$. doi:10.1111/bjep.12178

Lo, B. C. Y., Lai, R. N. M., Ng, T. K., \& Wang, H. (2020). Worry and Permissive Parenting in Association with the Development of Internet Addiction in Children. International journal of environmental research and public health, 17(21), 7722.

Ma, J., \& Grogan-Kaylor, A. (2017). Longitudinal associations of neighborhood collective efficacy and maternal corporal punishment with behavior problems in early childhood. Developmental psychology, 53(6), 1027-1041. doi:10.1037/dev0000308

Maguire-Jack, K., \& Klein, S. (2015). Parenting and proximity to social services: Lessons from Los Angeles County in the community context of child neglect. Child Abuse and Neglect, 45, 35-45. doi:10.1016/j.chiabu.2015.04.020

Marini, C. M., Collins, C. L., \& MacDermid Wadsworth, S. M. (2018). Examining Multiple Rhythms of Military and Veteran Family Life. Journal of Family Theory and Review, 10(3), 516-534. doi:10.1111/jftr.12275

Mistretta, R. M. (2020). Learning with and from School-Aged Children: Implications for Mathematics Methods Coursework Design. Investigations in Mathematics Learning. doi:10.1080/19477503.2020.1811025

Moscarola, F. C., Fornero, E., \& Rossi, M. (2018). The family as an informal market and the (low) mobility of the Italian young. Politica Economica, 34(1), 45-78. doi:10.1429/89709

Negreiros, J., Ballester, L., Valero, M., Carmo, R., \& Gama, J. D. (2019). A Systematic review of participation in prevention family programs. Pedagogia Social(34), 63-75. doi:10.7179/PSRI_2019.34.05

Neuman, S. B., \& Knapczyk, J. J. (2020). Reaching Families Where They Are: Examining an Innovative Book Distribution Program. Urban Education, 55(4), 542-569. doi:10.1177/0042085918770722

Niec, L. N. (2018). Parent-child interaction therapy: A transdiagnostic intervention to enhance family functioning. In Handbook of Parent-Child Interaction Therapy: Innovations and Applications for Research and Practice (pp. 3-15): Springer International Publishing.

Nihayati, H. E., Sholihah, N. N. M. a., \& Qonaah, A. (2020). The Relationship of Parenting and Juvenile Delinquency Rate in Flats. Systematic Reviews in Pharmacy, 11(3), 838-841.

Piermattei, C., Pace, C. S., Tambelli, R., D’Onofrio, E., \& Di Folco, S. (2017). Late Adoptions: Attachment Security and Emotional Availability in Mother-Child and Father-Child Dyads. Journal of Child and Family Studies, 26(8), 2114-2125. doi:10.1007/s10826-017-0732-6

Popa, A. R. (2018) Advertisements for children's products in women's magazines: Traits of the discourse. In: Vol. 17. Gender Studies (pp. 94-104): Sciendo.

Radey, M., Schelbe, L., McWey, L. M., \& Holtrop, K. (2017). Me, myself and I: perceptions of social capital for mothers ageing out of the child welfare system. Child and Family Social Work, 22(2), 981-991. doi:10.1111/cfs.12318

Rebollo, J. G., \& González, J. L. M. (2019). Networks of care among families with internationally adopted children in spain. Papers, 104(3), 525-543. doi:10.5565/rev/papers.2584

Rodriguez, G., Hartley, S. L., \& Bolt, D. (2019). Transactional relations between parenting stress and child autism symptoms and behavior problems. Journal of Autism and Developmental Disorders, 49(5), 1887-1898.

Rote, W. M., \& Smetana, J. G. (2018). Within-family dyadic patterns of parental monitoring and adolescent information management. Developmental psychology, 54(12), 2302-2315. doi:10.1037/dev0000615

Sacchi, P., \& Viazzo, P. P. (2018). Families and the elderly along the shores of the mediterranean: Old and new forms of relatedness. Ethnologie Francaise, 171(3), 427-438. doi:10.3917/ethn.183.0427

Sadik, F. (2018). Children and discipline: Investigating secondary school students' perception of discipline through metaphors. European Journal of Educational Research, 7(1), 31-44. doi:10.12973/eu-jer.7.1.31

Schoeps, K., Valero-Moreno, S., Perona, A. B., Pérez-Marín, M., \& Montoya-Castilla, I. (2020). Childhood adaptation: Perception of the parenting style and the anxious-depressive symptomatology. Journal for Specialists in Pediatric Nursing, 25(4). doi:10.1111/jspn.12306

Sette, S., Baldwin, D., Zava, F., Baumgartner, E., \& Coplan, R. J. (2019). Shame on me? Shyness, social experiences at preschool, and young children's self-conscious emotions. Early Childhood Research Quarterly, 47, 229-238. doi:10.1016/j.ecresq.2018.12.012 
Shawler, P., \& Funderburk, B. (2019). A clinical description of parent-child interaction therapy. In Handbook of Parent-Child Interaction Therapy for Children on the Autism Spectrum (pp. 237-250): Springer International Publishing.

Sidabrienė, J. (2014). Some of primary school students artistic individuality recognition aspects. Pedagogika, 113(1), 90-99. Retrieved from https://www.scopus.com/inward/record.uri?eid=2-s2.0 84929253125\&partnerID $=40 \&$ md5 $=$ c403850e479c81d7ce42a0f0a5254d93

Simon, J. D., \& Brooks, D. (2019). Targeting services to reduce need after a child abuse investigation: Examining complex needs, matched services, and meaningful change. Children and Youth Services Review, 99, 386-394. doi:10.1016/j.childyouth.2019.02.001

Simons, R. L., Wu, C. I., Conger, R. D., \& Lorenz, F. O. (2017). Two routes to delinquency: Differences between early and late starters in the impact of parenting and deviant peers. In Developmental and Lifecourse Criminological Theories (pp. 201-230): Taylor and Francis.

Tadjuddin, N., Elfiah, R., Meriyati, M., Wekke, I. S., \& Saregar, A. (2019). The interaction of children's early moral development process through a holistic approach. International Journal of Innovation, Creativity and Change, 8(9), 126-142. Retrieved from https://www.scopus.com/inward/record.uri?eid=2-s2.085077690237\&partnerID $=40 \&$ md5 $=86 \mathrm{ad} 81 \mathrm{c} 5 \mathrm{e} 79 \mathrm{~b} 881 \mathrm{~b} 4 \mathrm{dbf} 90120 \mathrm{~d} 05 \mathrm{bebe}$

Taylor, M. F., Marquis, R., Coall, D. A., \& Werner, J. (2018). The Enjoyment Rewards of Fulfilling a Custodial Grandparenting Role in the Lives of Grandchildren Removed from their Parents' Care. Child Care in Practice, 24(1), 92-110. doi:10.1080/13575279.2017.1297772

Theisen, T., \& Emblem, A. W. (2018). House prices and proximity to kindergarten-costs of distance and external effects? Journal of Property Research, 35(4), 321-343. doi:10.1080/09599916.2018.1513057

Tieken, M. C. (2020). "We Don't Know How to Do This": Rural Parents' Perspectives on and Roles in Enrollment at a Private, Selective Liberal Arts College. Rural Sociology, 85(3), 706-729. doi:10.1111/ruso.12316

Tissot, H., Kuersten-Hogan, R., Frascarolo, F., Favez, N., \& McHale, J. P. (2019). Parental Perceptions of Individual and Dyadic Adjustment as Predictors of Observed Coparenting Cohesion: A Cross-National Study. Family Process, 58(1), 129-145. doi:10.1111/famp.12359

Tu, K. M., Gregson, K. D., Erath, S. A., \& Pettit, G. S. (2017). Custom-Fit Parenting: How Low- and WellAccepted Young Adolescents Benefit from Peer-Related Parenting. Parenting, 17(3), 157-176. doi:10.1080/15295192.2017.1332298

Wang, M., \& Liu, L. (2018). Reciprocal Relations Between Harsh Discipline and Children's Externalizing Behavior in China: A 5-Year Longitudinal Study. Child development, 89(1), 174-187. doi:10.1111/cdev.12724

Westford, P. (2018). Adapting school siting to school choice and compact city policies. International Journal of Sustainable Development and Planning, 13(2), 329-337. doi:10.2495/SDP-V13-N2-329-337 